\title{
Cephalometric Norms Among Qatari Females
}

\author{
Hayder Abdalla Hashim, Najah AL-Sayed, Ayah AL-Qaisi
}

\begin{abstract}
Aims: The aims of this study were to introduce cephalometric norms for Qatari females and compare the result with previous published reports.

Material and method: The sample consisted of 57 cephalographs with age range 18 to 25 years old. All subjects satisfied the criteria of selection. Cephalometric measurements of Qatari females were then compared with Eastman Standard norms and Arabs studies as well as reports conducted among Oriental and Black races.

Results: The result indicates that Qatari females presented with higher mean values of sagittal and vertical relationship compared to Caucasian cephalometric norms. In terms of dental variables proclined upper and lower incisors in relation to their dental bases, and a reduction in inter-incisal angle. The soft tissue variables indicate that the lips were slightly protrusive in relation to Rickett's esthetic line, and the nasolabial angle was less obtuse. The bimaxillary proclination and protrusion of the upper and lower incisors were existed in all Arab populations as well as in Black and Oriental races whereas the Caucasian had retrusive dentition.

Conclusion: Due to limitation of the present study, it is difficult to draw a solid conclusion due to small sample size. Hence, large sample size is recommended for both sexes in order to establish cephalometric norms which will be of great help not only to the orthodontist but also to the oral and maxillofacial surgeon as well as the pedodontist.
\end{abstract}

Index Terms - Cephalometric Norms, Caucasian, Orthodontic treatment, racial groups.

\section{INTRODUCTION}

The cephalography is a two-dimensional representation of three-dimension object. It is considered as the eye of the orthodontist. Broadbent [1] in the United States and Hofroth [2] in Germany were the first who introduced cephalometric radiograph. It is mostly used to describe the morphology and the growth of the facial skeleton, predict growth, plan treatment and evaluate treatment results. Further, cephalometric analysis is commonly carried out by tracing or digital model that highlights the relationship of selected points.

The goal of cephalometric analysis is to determine the skeletal and dental relationships that exist in an individual patient. This is provided by comparing the patients with a normal reference group, so that differences between the patient's actual dento-facial relationships and those expected for his or her racial or ethnic group are revealed. However, different cephalometric analyses were introduced in the field of orthodontics. Among these are Down's 1949, Steiner 1954, Tweed 1954, Ballard 1954, Sassouni 1955, Ricketts 1961,
Jacobson 1975, McNamara 1984 [1] - [10].

Cephalometric measurements show variances in different racial and ethnic groups have been presented in several studies. Numerous cephalometric studies were conducted comparing the dentofacial characteristics of Caucasians with non-Caucasians as Japanese, Chinese, Filipino's (Oriental), Africans (Black), and Afro-Americans (Black), and Arabs. However, most studies indicated that, the Black and the Oriental had the most protrusive dentition and the Caucasians had the most retrusive dentition [9] -[12].

John et al introduced Chinese norms of McNamara's cephalometric analysis and found that, the mandibular plane angle, SNA, maxilla-mandibular difference, upper incisor to point A vertical, and lower incisor to A-Po (A-pogonion) line were larger in the Chinese than in the Caucasian subjects. On the other hand, effective midface length, facial axis angle, and pogonion-to-nasion perpendicular were larger in the Caucasians compared to the Chinese subjects [13].

Steiner's cephalometric norms for the Nepalese and IndoAryan population indicates that, the Nepalese Indo-Aryan sample had a shorter anterior cranial base, longer posterior cranial base, more prognathic maxilla, a more anteriorly placed mandibular base, more protrusive upper incisors, and more protrusive lips when compared with Caucasian ideal values. Further, the result depicted that, the Black had the most protrusive dentition and the Caucasians had the most retrusive dentition [14].

Janson and coworkers did study to compare the skeletal, dental, and soft tissue characteristics of Caucasian and AfroCaucasian Brazilian subjects each group consisted of 40 subjects with normal occlusion and to evaluate sexual dimorphism within the groups. They concluded that Brazilian Afro-Caucasian subjects presented greater maxillary protrusion, smaller upper and lower anterior face height, larger upper posterior facial height, and greater maxillary and mandibular dentoalveolar protrusion as well as soft tissue protrusion compared to Caucasian subjects [15]. Ajayi studied 100 standardized lateral cepahalograhs of Nigerian schoolchildren with a well-balanced face and acceptable profile. He found that the Children have prognathic relationship of the maxilla and the mandible to the anterior cranial base with a tendency toward a protrusive skeletal pattern. Also, the result revealed prominent bimaxillary proclination with procumbent and protrusive maxillary and mandibular incisors and a steep Frankfort-mandibular plane angle [16].

Hamdan and Rock identify cephalometric norms for Jordanian population. They found MMPA was lower in the Jordanian population. Both upper and lower incisors were 
proclaimed significantly compared to Eastman Standard [17].

Lahlou et al conducted a comparative study to evaluate bimaxillary protrusion among Moroccans and to compare the Moroccan population with other Arabic, Caucasian, and Mediterranean populations; since similar studies in Arabs and Moroccans are rare. The results exhibit that bimaxillary protrusion was more in the Moroccans than in the Caucasians [18]. Further, Bishara et al. did a comparative investigation between Egyptian and North American adolescents and found that Egyptian boys have a tendency toward bimaxillary dental protrusion and a decreased overbite as compared with Iowa boys. The Egyptian girls have a relatively more convex profile and a tendency towards mandibular dental protrusion [19].

Furthermore, Hashim and AL-Barakati investigated cephalometric soft tissue profile between Saudi males and females and compare the result with Caucasian Americans. The result showed no statistical significant differences between the Saudi males and females except for the angle of total facial convexity, soft tissue facial plane angle, lower lip length, sagittal nasal tip to the most protrusive lip distance, and also sagittal chin to the most protrusive lip distance.[20] Hassan studied Class II division 1 malocclusion in Saudi children living in the western region and observed the following: significantly increased ANB angle, more prognathic maxilla, normal mandibular position and proclaimed upper incisors [21]. On the other hand, AL-Zain and Ferguson stated "Emiratis are likely to present greater incisor proclination and protrusion than Caucasians and may be generally considered as more bimaxillary protrusive" [22]. The aims of this investigation were to present cephalometric norms in Qatari females and to compare the skeletal, dentoalveolar and soft tissue characteristics with previous reports in different racial groups.

\section{MATERIAL AND METHODS}

The sample comprised 57 lateral skull radiographs of females aged 18 to 25 years old seeking orthodontic treatment. They were selected according to the following criteria: well-balanced face and acceptable profile, Class I occlusion with normal overjet and overbite, minor or no crowding or spacing, and no history of orthodontic treatment. Ethical approval and consent form were obtained.

Lateral cephalograms were manually traced by one operator (A.A) and analyzed based on Steiner's cephalometric variables.

\section{A. Statistical Analysis}

Student's t-test was used to assess the error of the method, and to compare the result of the present study with the previous published cephalometric norms in different races. Significant level was set at $\mathrm{P}<0.05$.

\section{RESULTS}

\section{A. Error of the method}

An error analysis was performed using five cephalographs. Each radiograph was traced and retraced with one-week interval. The results of the analysis revealed that there were no significant differences between the two readings. Table I, Table II and Fig 1 exhibited the mean, standard deviation of the skeletal, dental and soft tissue features in Qatari females. Compared to Steiner's cephalometric norms; the sagittal relationship showed an orthognathic maxilla ( SNA 82.68) and mandible (SNB 79.82) with skeletal Class I relationship (ANB 2.96).The SNPog (81.33) indicates slightly prominent chin with normally inclined saddle angle (N-S-Ba 133.19).The vertical relationship revealed that; the maxilla was normally incline anteriorly NL-SNL (8.83) and the mandible (ML-SNL 33.65) was posteriorly inclined in relation to anterior cranial base with slight open basal configuration (ML-NL 27.21).

Dentally, the upper and lower incisors were proclined and protruded leading to reduced intercisal angle. The soft tissue showed that, the upper lip and lower lip were slightly protruded and the nasolabial angle was less obtused. In general, the cephalometric norms in Qatari females were very close to Steiner's norms.

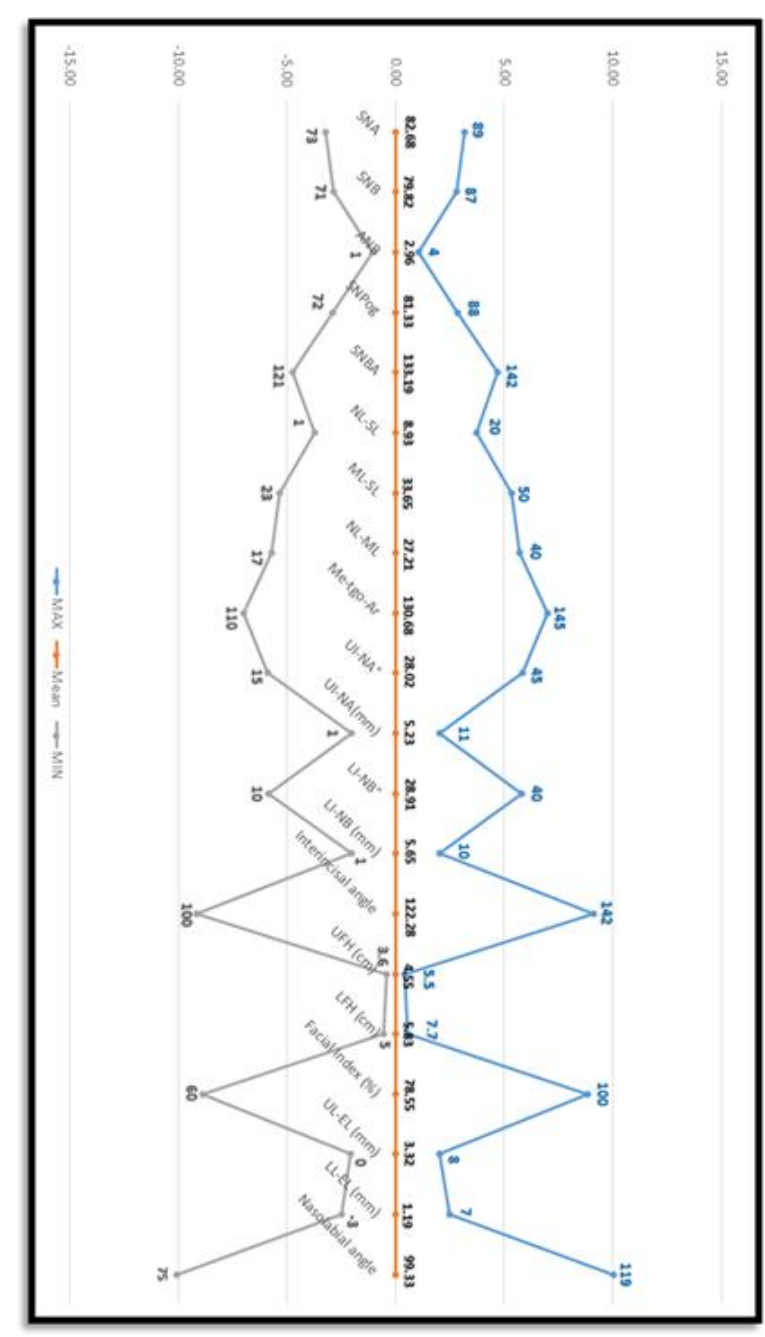

Fig 1. Polygon of Qatari females. 
TABLE I: ERROR OF THE METHOD

\begin{tabular}{|c|c|c|c|c|c|c|c|}
\hline Variable & Patient 1 & Patient 2 & Patient 3 & Patient 4 & Patient 5 & $\mathrm{P}:$ value & Significance \\
\hline SNA $\left(1^{\text {st }}\right)$ & 80 & 85 & 80 & 80 & 78 & \multirow{2}{*}{1} & \multirow{2}{*}{ NS } \\
\hline SNA $\left(2^{\text {nd }}\right)$ & 80 & 85 & 80 & 80 & 78 & & \\
\hline SNB $\left(1^{\text {st }}\right)$ & 76 & 82 & 75 & 78 & 78 & \multirow{2}{*}{0.905} & \multirow{2}{*}{ NS } \\
\hline SNB $\left(2^{\text {nd }}\right)$ & 76 & 82 & 76 & 78 & 78 & & \\
\hline ANB $\left(1^{\text {st }}\right)$ & 4 & 3 & 5 & 2 & 0 & \multirow{2}{*}{0.865} & \multirow{2}{*}{ NS } \\
\hline ANB $\left(2^{\text {nd }}\right)$ & 4 & 3 & 4 & 2 & 0 & & \\
\hline $\mathrm{SNBa}\left(1^{\mathrm{st}}\right)$ & 130 & 134 & 144 & 81 & 140 & \multirow{2}{*}{0.961} & \multirow{2}{*}{ NS } \\
\hline $\mathrm{SNBa}\left(2^{\text {nd }}\right)$ & 130 & 134 & 140 & 81 & 140 & & \\
\hline SNPog $\left(1^{\text {st }}\right)$ & 77 & 84 & 77 & 135 & 82 & \multirow{2}{*}{1} & \multirow{2}{*}{ NS } \\
\hline $\operatorname{SNPog}\left(2^{\text {nd }}\right)$ & 77 & 84 & 77 & 135 & 82 & & \\
\hline $\operatorname{MeTgoAr}\left(1^{\mathrm{st}}\right)$ & 120 & 135 & 120 & 133 & 120 & \multirow{2}{*}{0.867} & \multirow{2}{*}{ NS } \\
\hline $\operatorname{MeTgoAr}\left(2^{\text {nd }}\right)$ & 120 & 135 & 125 & 132 & 120 & & \\
\hline SL-NL $\left(1^{\text {st }}\right)$ & 13 & 5 & 15 & 12 & 11 & \multirow{2}{*}{0.817} & \multirow{2}{*}{ NS } \\
\hline SL-NL $\left(2^{\text {nd }}\right)$ & 13 & 4 & 15 & 10 & 11 & & \\
\hline SL-ML $\left(1^{\text {st }}\right)$ & 32 & 33 & 34 & 37 & 23 & \multirow{2}{*}{0.913} & \multirow{2}{*}{ NS } \\
\hline SL-ML $\left(2^{\text {nd }}\right)$ & 30 & 32 & 37 & 36 & 22 & & \\
\hline ML-NL $\left(1^{\text {st }}\right)$ & 18 & 35 & 21 & 26 & 12 & \multirow{2}{*}{0.895} & \multirow{2}{*}{ NS } \\
\hline ML-NL $\left(2^{\text {nd }}\right)$ & 13 & 35 & 24 & 25 & 11 & & \\
\hline UI-NA $\left(1^{\text {st }}\right)$ & 18 & 24 & 27 & 20 & 30 & \multirow{2}{*}{0.792} & \multirow{2}{*}{ NS } \\
\hline UI-NA $\left(2^{\text {nd }}\right)$ & 18 & 24 & 25 & 26 & 30 & & \\
\hline UI-NA $\left(1^{\text {st }}\right)$ & 3 & 4 & 4 & 4 & 3 & \multirow{2}{*}{0.681} & \multirow{2}{*}{ NS } \\
\hline $\mathrm{UI}-\mathrm{NA}\left(2^{\text {nd }}\right)$ & 2 & 4 & 4 & 4 & 3 & & \\
\hline LI-NB $\left(1^{\text {st }}\right)$ & 28 & 27 & 38 & 22 & 10 & \multirow{2}{*}{0.920} & \multirow{2}{*}{ NS } \\
\hline LI-NB $\left(2^{\text {nd }}\right)$ & 26 & 26 & 35 & 22 & 13 & & \\
\hline LI--NB $\left(1^{\text {st }}\right)$ & 5 & 6 & 6 & 3 & -1 & \multirow{2}{*}{0.923} & \multirow[b]{2}{*}{ NS } \\
\hline LI--NB $\left(2^{\text {nd }}\right)$ & 5 & 6 & 6 & 3 & -2 & & \\
\hline UI-LI $\left(1^{\text {st }}\right)$ & 130 & 128 & 115 & 136 & 40 & \multirow{2}{*}{0.988} & NS \\
\hline UI-LI $\left(2^{\text {nd }}\right)$ & 130 & 127 & 120 & 130 & 40 & & NS \\
\hline TAFH $\left(1^{\text {st }}\right)$ & 9,6 & 11 & 10 & 10 & 9,9 & & \\
\hline TAFH $\left(2^{\text {nd }}\right)$ & 9,7 & 11 & 10 & 10 & 9,8 & 1 & NS \\
\hline EL-UL $\left(1^{\text {st }}\right)$ & 6 & 3 & 4 & 2 & 8 & & \\
\hline EL-UL $\left(2^{\text {nd }}\right)$ & 6 & 3 & 4 & 1 & 9 & 1 & NS \\
\hline EL-LL $\left(1^{\text {st }}\right)$ & 2 & 1 & 3 & -1 & 9 & 0032 & NS \\
\hline EL-LL $\left(2^{\text {nd }}\right)$ & 2 & 1 & 3 & -1 & 8 & 0.932 & NS \\
\hline Nisolibal angle $\left(1^{\text {st }}\right)$ & 100 & 115 & 100 & 114 & 113 & & \\
\hline Nisolibal angle $\left(2^{\text {nd }}\right)$ & 98 & 116 & 100 & 117 & 115 & 0.886 & NS \\
\hline
\end{tabular}

P>0.05 N.S.

TABLE II: CEPHALOMETRIC MEAN VALUES AND STANDARD DEVIATION OF QATARI FEMALES AND STEINER'S CEPHALOMETRIC NORMS

\begin{tabular}{|l|l|l|l|l|}
\hline \multirow{2}{*}{ Variables } & Qatari & Females & Steiner's & Norms \\
\cline { 2 - 5 } & Mean & SD & Mean & SD \\
\hline SNA $^{\circ}$ & 82.68 & 3.19 & 82 & 3 \\
\hline SNB $^{\circ}$ & 79.82 & 2.87 & 80 & 3 \\
\hline ANB $^{\circ}$ & 2.96 & 1.05 & 2 & 2 \\
\hline SN Pog $^{\circ}$ & 81.33 & 2.87 & 81 & 3 \\
\hline N-S-Ba $^{\circ}$ & 133.19 & 4.71 & 132 & 4 \\
\hline NL-SNL $^{\circ}$ & 8.93 & 3.74 & 8.5 & 4 \\
\hline ML-SNL $^{\circ}$ & 33.65 & 5.34 & 32 & 5 \\
\hline NL-ML $^{\circ}$ & 27.21 & 5.7 & 23.5 & 7 \\
\hline Me-tgo-Ar $^{\circ}$ & 130.69 & 6.99 & 126 & 7 \\
\hline Facial Index (\%) $^{\circ}$ & $78.55 \%$ & 8.86 & $79 \%$ & \\
\hline UI-NA $^{\circ}$ & 28.02 & 5.87 & 22 & 4 \\
\hline UI-NA (mm) $^{\circ}$ & 5.23 & 2.04 & 4 & \\
\hline LI-NB $^{\circ}$ & 28.91 & 5.82 & 25 & 4 \\
\hline LI-NB (mm) & 5.65 & 2.03 & 4 & \\
\hline UI-LI & 122.28 & 9.14 & 130 & \\
\hline UL-EL (mm) & 3.32 & 2.05 & 2 & 2 \\
\hline LL-EL (mm) & 1.19 & 2.47 & 0 & 2 \\
\hline Nasolabial & \\
\hline & 99.33 & 10.06 & $90-110$ & \\
\hline
\end{tabular}

Table III showed the comparison between the Qatari females and Jordanian females. The result revealed that the Qatari females had significantly higher mean values in sagittal and vertical relationship as well as lesser reduced interincisal angle in the Qatari females. No significant difference was noticed in ANB angle.
TABLE III: COMPARISON OF SAMPLE MEANS BETWEEN QATARI FEMALES AND JORDANIAN FEMALES

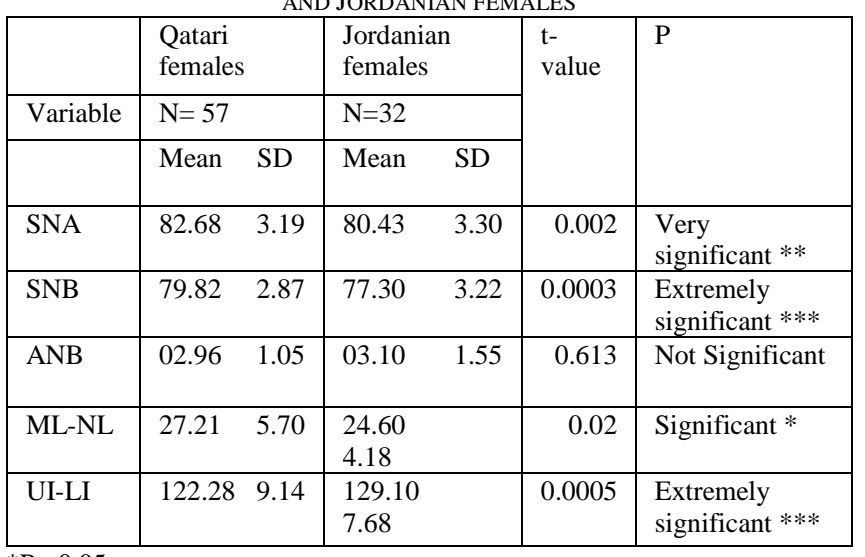

$* \mathrm{P}<0.05$.

$* * \mathrm{P}<0.01$

$* * * \mathrm{P}<0.001$.

Table IV displayed the comparison between Qatari females and Emirati females. The SNA and SNB angles in Qatari females were significantly higher than that in Emirati females. In the other hand, the lower incisor and the mandibular inclination in Emirati females was significantly higher compared to Qatari females $(\mathrm{P}<0.05)$. 
TABLE IV: COMPARISON OF SAMPLE MEANS BETWEEN QATARI FEMALES AND EMIRATI FEMALES

\begin{tabular}{|l|cc|cc|c|c|}
\hline & \multicolumn{2}{|c|}{$\begin{array}{c}\text { Qatari } \\
\text { females }\end{array}$} & \multicolumn{2}{|c|}{ Emirati } & \multirow{2}{*}{$\begin{array}{c}\text { t- } \\
\text { Value }\end{array}$} & \multirow{2}{*}{$\mathrm{P}$} \\
\hline Variable & N=57 & N=61 & & \\
\hline & Mean & SD & Mean & SD & & Significant * \\
\hline SNB & 82.68 & 3.19 & 80.8 & 5.64 & 0.0292 & $\begin{array}{c}\text { Very } \\
\text { Significant } \\
* *\end{array}$ \\
\hline ANB & 79.82 & 2.87 & 77.6 & 4.82 & 0.0032 & $\begin{array}{c}\text { Not } \\
\text { significant }\end{array}$ \\
\hline ML-SNL & 33.65 & 5.34 & 35.9 & 7.0 & 0.014 & Significant \\
\hline NL-SNL & 8.93 & 3.74 & 10.7 & 3.95 & 0.0532 & $\begin{array}{c}\text { Not } \\
\text { significant }\end{array}$ \\
\hline UI-LI & 122.28 & 9.14 & 118.7 & 10.51 & 0.0514 & $\begin{array}{c}\text { Not } \\
\text { Significant }\end{array}$ \\
\hline UI-NAmm & 5.23 & 2.04 & 6.2 & 3.18 & 0.0528 & $\begin{array}{c}\text { Not } \\
\text { Significant }\end{array}$ \\
\hline LI-NB mm & 5.65 & 2.03 & 6.6 & 10.51 & 0.0458 & Significant * \\
\hline
\end{tabular}

$* \mathrm{P}<0.05$.

$* * \mathrm{P}<0.01$.

$* * * \mathrm{P}<0.001$.

Table V demonstrated that the Qatari and Omani Arab descent show no statistically significant differences in sagittal and vertical skeletal relationship. The dental relationship indicates significant differences at 5\% level in upper lip to esthetic line and extremely significant in lower lip to Ricketts esthetic line. Also, the nasolabial angle in Omani Arab descent was extremely significant more obtused than in Qatari females

TABLE V: COMPARISON OF SAMPLE MEANS BETWEEN QATARI FEMALES AND OMANI ARAB DESCENT

\begin{tabular}{|c|c|c|c|c|c|}
\hline \multirow[t]{2}{*}{ Variable } & $\begin{array}{l}\text { Qatari } \\
\mathrm{N}=57\end{array}$ & \multicolumn{2}{|c|}{$\begin{array}{l}\text { Omani } \\
\mathrm{N}=91\end{array}$} & \multirow{2}{*}{$\begin{array}{c}\mathrm{P}- \\
\text { Value }\end{array}$} & \multirow[t]{2}{*}{ Comment } \\
\hline & Mean SD & Mean & SD & & \\
\hline SNA & 82.683 .19 & 81.44 & 4.23 & 0.0159 & Not significant \\
\hline SNB & $\begin{array}{ll}79.82 & 2.87 \\
\end{array}$ & 78.98 & 3.92 & 0.1639 & Not significant \\
\hline ANB & $\begin{array}{ll}2.96 & 1.05 \\
\end{array}$ & 2.64 & 231 & 0.1266 & Not significant \\
\hline PP-MM & $27.21 \quad 5.70$ & 25.95 & 5.15 & 0.1667 & Not significant \\
\hline UI-LI deg & 122.289 .14 & 121.7 & 11.59 & 0.782 & Not significant \\
\hline UL-EL mm & $3.32 \quad 2.05$ & 2.43 & 2.86 & 0.0429 & Significant \\
\hline LL-EL mm & $1.32 \quad 2.47$ & -0.7 & 1.83 & 0.0001 & $\begin{array}{c}\text { Extremely } \\
\text { Significant } * * *\end{array}$ \\
\hline $\begin{array}{l}\text { Nasolabial } \\
\text { angle }\end{array}$ & 99.3310 .06 & 105.3 & 10.34 & 0.0007 & $\begin{array}{c}\text { Extremely } \\
\text { Significant } * * *\end{array}$ \\
\hline
\end{tabular}

Table VI showed that there were no statistically significant differences in most of the variables except for the upper incisor proclination and mandibular inclination to cranial base where Qatari females revealed higher mean values compared to Saudi females. $(\mathrm{P}<0.05)$.

Table VII indicated that Qatari females had higher mean values in the sagittal relationships, interincisal angle and lower lip to esthetic line $(\mathrm{P}<0.001)$. Also, there a significant difference at $5 \%$ level in inter-jaw angle (NL-ML) and upper lip to esthetic line. In the other hand, no statistically significant differences were found in NL-SNL angle and in ANB when compared to Eastman Standard $(\mathrm{P}>0.05)$.
TABLE VI: COMPARISON BETWEEN QATARI FEMALE AND SAUDI FEMALES

\begin{tabular}{|c|c|c|c|c|c|c|}
\hline \multirow{2}{*}{$\begin{array}{l}\text { Parame } \\
\text { ter }\end{array}$} & \multicolumn{2}{|c|}{ Qatari } & \multicolumn{2}{|c|}{ Saudi } & \multirow[t]{2}{*}{ P-value } & \multirow{2}{*}{ Comment } \\
\hline & Mean & SD & Mean & $\mathrm{SD}$ & & \\
\hline $\mathrm{SNA}^{\circ}$ & 82.68 & 3.19 & 83.6 & 4.3 & 0.2614 & $\begin{array}{c}\text { Not } \\
\text { significant }\end{array}$ \\
\hline $\mathrm{SNB}^{\circ}$ & 79.82 & 2.87 & 81. & 3.7 & 0.1034 & $\begin{array}{c}\text { Not } \\
\text { significant }\end{array}$ \\
\hline $\mathrm{ANB}^{\circ}$ & 2.96 & 1.05 & 2.5 & 2 & 0.1621 & $\begin{array}{c}\text { Not } \\
\text { significant }\end{array}$ \\
\hline $\begin{array}{l}\text { UI- } \\
\mathrm{NA}^{\circ} \\
\end{array}$ & 28.02 & 5.87 & 24.8 & 5.6 & 0.0155 & Significant $*$ \\
\hline $\begin{array}{l}\text { UI-NA } \\
(\mathrm{mm})\end{array}$ & 5.23 & 2.04 & 5.3 & 2.6 & 0.8905 & $\begin{array}{c}\text { Not } \\
\text { significant }\end{array}$ \\
\hline $\mathrm{LI}^{-N B}{ }^{\circ}$ & 28.91 & 5.82 & 27.8 & 4.3 & 0.3603 & $\begin{array}{c}\text { Not } \\
\text { significant }\end{array}$ \\
\hline $\begin{array}{l}\text { LI-NB } \\
(\mathrm{mm})\end{array}$ & 5.65 & 2.03 & 6.1 & 2.1 & 0.3340 & $\begin{array}{c}\text { Not } \\
\text { significant }\end{array}$ \\
\hline UI-LI & 122.28 & 9.14 & 124.8 & 6.9 & 0.1893 & $\begin{array}{c}\text { Not } \\
\text { significant }\end{array}$ \\
\hline ML-SN & 33.65 & 5.34 & 31 & 5.1 & 0.0281 & Significant $*$ \\
\hline
\end{tabular}

TABLE VII: COMPARISON OF SAMPLE MEANS BETWEEN QATARI FEMALES AND EASTMAN STANDARD

\begin{tabular}{|c|c|c|c|c|c|c|}
\hline \multirow{3}{*}{ Variable } & \multirow{2}{*}{\multicolumn{2}{|c|}{$\begin{array}{c}\begin{array}{c}\text { Qatari } \\
\text { females }\end{array} \\
\mathrm{N}=57\end{array}$}} & \multirow{2}{*}{\multicolumn{2}{|c|}{$\begin{array}{c}\text { Eastman } \\
\text { Standard }\end{array}$}} & \multirow{3}{*}{ t-Value } & \multirow{3}{*}{$\mathrm{P}$} \\
\hline & & & & & & \\
\hline & Mean & $\mathrm{SD}$ & Mean & SD & & \\
\hline SNA & 82.68 & 3.19 & 81 & 3 & 0.0002 & $\begin{array}{c}\text { Extremely } \\
\text { Significant } * * *\end{array}$ \\
\hline SNB & 79.82 & 2.87 & 78 & 3 & 0.0001 & $\begin{array}{c}\text { Extremely } \\
\text { Significant } * * *\end{array}$ \\
\hline ANB & 2.96 & 1.05 & 3 & 2 & 0.883 & Not significant \\
\hline ML-NL & 27.21 & 5.70 & 25 & 6 & 0.0118 & Significant \\
\hline NL-SNL & 8.93 & 3.74 & 9.22 & 3.56 & 0.5904 & Not significant \\
\hline UI-LI & 122.28 & 9.14 & 131 & 6 & 0.0001 & $\begin{array}{c}\text { Extremely } \\
\text { Significant } * * *\end{array}$ \\
\hline UL-EL & 3.32 & 2.05 & 2.43 & 2.86 & 0.027 & Significant $*$ \\
\hline ELL-EL & 1.19 & 2.47 & -0.7 & 1.84 & 0.0001 & $\begin{array}{c}\text { Extremely } \\
\text { Significant } * * *\end{array}$ \\
\hline
\end{tabular}

$* \mathrm{P}<0.05$.

$* * \mathrm{P}<0.01$.

$* * * \mathrm{P}<0.001$

Table VIII exhibited that, the Black Brazilian revealed higher statistically significant differences in the sagittal skeletal relationship indicating prognathic maxilla and mandible than that in Qatari females. The dental relationship depicted significant bimaxillary proclination and protrusion of lower incisors compared to Qatari females. The soft tissue relationship of the Black Brazilian exhibited protruded lower lip due to increased proclination of lower incisor while no protrusion was observed in the upper lip. The Nasolabial angle was highly significantly acute in Black Brazilian whereas in Qatari females was slightly obtused $(\mathrm{P}>0.001)$.

Table IX, demonstrated that there were no significant differences in the sagittal relatioship. Significant difference were noted in the maxillary inclination to the cranial base $(\mathrm{P}>0.05)$ and the jaw angle $(\mathrm{P}<0.01)$. In the other hand, the interincisal angle was extremly significanly reduced in Filipino females when compared to Qatari females . In the other hand, the Qatari female exhibits very significant increased of the jaw angle. 
TABLE VIII: COMPARISON OF SAMPLE MEANS BETWEEN QATARI FEMALES

\begin{tabular}{|c|c|c|c|c|c|}
\hline \multirow{2}{*}{ Variable } & $\begin{array}{l}\text { Qatari } \\
\mathrm{N}=57\end{array}$ & \multirow{2}{*}{\multicolumn{2}{|c|}{$\begin{array}{c}\begin{array}{c}\text { Black } \\
\text { Brazilian }\end{array} \\
\mathrm{N}=50\end{array}$}} & \multirow{2}{*}{$\begin{array}{c}\mathrm{t}- \\
\text { Value }\end{array}$} & \multirow{2}{*}{$P$} \\
\hline & & & & & \\
\hline SNA & 82.683 .19 & 86.95 & 3.89 & 0.0001 & $\begin{array}{c}\text { Extremely } \\
\text { Significant*** }\end{array}$ \\
\hline SNB & 79.822 .87 & 82.95 & 3.52 & 0.0001 & $\begin{array}{c}\text { Extremely } \\
\text { Significant*** }\end{array}$ \\
\hline ANB & $2.96 \quad 1.05$ & 3.99 & 2.17 & 0.0019 & $\begin{array}{c}\text { Very Significant } \\
* *\end{array}$ \\
\hline UI-NA deg & 28.025 .87 & 24.92 & 5.43 & 0.0057 & $\begin{array}{c}\text { Very Significant } \\
* *\end{array}$ \\
\hline UI-NA mm & $5.23 \quad 2.04$ & 6.06 & 2.76 & 0.0718 & Not Significant \\
\hline LI-NB deg & 28.915 .82 & 35.99 & 5.92 & 0.0001 & $\begin{array}{c}\text { Extremely } \\
\text { Significant } * * * \\
\end{array}$ \\
\hline LI-NB mm & $\begin{array}{ll}5.65 & 2.03 \\
\end{array}$ & 8.14 & 2.23 & 0.0001 & $\begin{array}{c}\text { Extremely } \\
\text { Significant**** }\end{array}$ \\
\hline $\begin{array}{c}\text { UL-EL } \\
\mathrm{mm}\end{array}$ & $3.32 \quad 2.05$ & 0.16 & 2.59 & 0.0001 & $\begin{array}{c}\text { Extremely } \\
\text { Significant**** } \\
\end{array}$ \\
\hline LL-EL & $1.32 \quad 2.47$ & 3.51 & 2.32 & 0.0001 & $\begin{array}{c}\text { Extremely } \\
\text { Significant**** }\end{array}$ \\
\hline Nasolabial & 99.330 .06 & 89.31 & 12.4 & 0.0001 & $\begin{array}{c}\text { Extremely } \\
\text { Significant } * * *\end{array}$ \\
\hline
\end{tabular}

TABLE IX: COMPARISON OF SAMPLE MEANS BETWEEN QATARI FEMALES

\begin{tabular}{|c|c|c|c|c|c|}
\hline \multicolumn{6}{|c|}{ AND FILIPINO FEMALES } \\
\hline Variable & Qatari & Filipi & & $\begin{array}{c}\text { P- } \\
\text { Value }\end{array}$ & Comment \\
\hline & $\mathrm{N}=57$ & $\mathrm{~N}=$ & & & \\
\hline & Mean SD & Mean & & & \\
\hline SNA & 82.683 .19 & 82.9 & 3.6 & 0.9091 & $\begin{array}{c}\text { Not } \\
\text { significant }\end{array}$ \\
\hline SNB & $79.82 \quad 2.87$ & 78.9 & 3.1 & 0.2393 & $\begin{array}{c}\text { Not } \\
\text { significant }\end{array}$ \\
\hline ANB & $2.96 \quad 1.05$ & 4.0 & 1.3 & 0.0007 & $\begin{array}{c}\text { Extremely } \\
\text { significant*** }\end{array}$ \\
\hline NL-SN & $6.044 \quad 3.74$ & 10.2 & 3.8 & 0.0001 & $\begin{array}{c}\text { Extremely } \\
\text { significant*** }\end{array}$ \\
\hline ML-SN & $33.65 \quad 5.34$ & 36.9 & 4.5 & 0.0197 & Significant* \\
\hline Ar.tgo-Me & 130.696 .99 & 125.6 & 5.2 & 0.0048 & $\begin{array}{c}\text { Very } \\
\text { significant** }\end{array}$ \\
\hline UI-LI deg & 122.289 .14 & 113.6 & 6.5 & 0.0003 & $\begin{array}{c}\text { Extremely } \\
\text { significant*** }\end{array}$ \\
\hline
\end{tabular}

$* \mathrm{P}<0.05$.

$* * \mathrm{P}<0.01$.

$* * * \mathrm{P}<0.001$

\section{DISCUSSION}

Cephalometric analysis is of paramount importance as a diagnostic tool in the assessment and analysis of orthodontic cases. Numerous research studies have been documented over a period of years, varying in the methodology used, the populations studied, and the findings. Therefore, there exists a need to document cephalometric norms of Qatari populations. The main objectives of orthodontic treatment is to restore the esthetic and function. Patient main concern is to have well aligned teeth and good smile. However, to reasch such result, we should discover the causitive factors and correct them. The skeletal, dental and soft tissue relationship should be checked before starting orthodontic treatment. These causitive factors can be obtained through proper clinical, dental photography, model analysis and radigraphic examinations. Cephalometric anlysis is considered as the eye of the orthodontist. Thus, it is sensitive not only to the position of teeth within a given bone, but also to the interrelationship between jaw elements and cranial base structures.[14] Thus, it is very important to consider each patient's treatment goals and needs during evaluation and treatment planning.

The accuracy of cephalometric analysis is important to allow the orthodntist to assess the results obtained from the collected data and provide the patient with various treatment options and outcomes.The conventional and digital analysis are two methods of cephalometric analysis and both methods are highly reliable..However, although the reproducibility of the two methods showed some statistically significant differences but most differences were not clinically significant.[23].In the present study, the conventional methd was used.Cephalometric norms of Caucasians indicates that there were measurable skeletal and dental differences when compared to non-Caucasians.[2,3] This will indicate that the mean values of one race is not applicable to the other races. This encourage researcher in different countries to investigate whether their cephalometric values were like the Caucasians norms. However, most of the reports indicate not to follow the Caucasian norms. Hence, Downs[2] and Steiner[3] suggested that their norms were to be used as guides and should not use as absolute values for every patient. This concept shed the light in a normal range of a racial group; different variety of facial patterns existed between the different races.

Numerous studies did show differences between racial groups exist. The cephalometric mean values of the Qatari females were compared to Caucasians norms published by Mills [6] Eastman Standard. It indicates that the Qatari females had statistically higher mean values in the SNA, $\mathrm{SNB}$, interincisal angle and lower lip to Esthetic line $(\mathrm{P}<$ 0.001). Also, there were significant difference at $5 \%$ level in inter-jaw angle (NL-ML) and upper lip to esthetic line. In the other hand, no statistically significant differences were found in the inclination of the maxilla to anterior cranial base and in ANB (P>0.05). Further, when the result of present study was compared with the cephalometric norms of the Jordaian[17], the result revealed that the Qatari females had significantly higher mean values in sagittal (SNA and SNB) and vertical ( MMPA) relationship $(\mathrm{P}<0.05)$ whilst the intericisal angle was significantly higher (129.10 degree) in Jordaians females than in Qatari females (122.28) indicating increased proclination and protrusion of the incisors in both Jordanians and Qatari females as well. $(\mathrm{P}<0.001)$ However, no significant difference was noticed in ANB angle.

In the other hand, when the present study was compared with the study carried out by Abu-Tayyem[24] among Emirati females, the result indcated that the Emirati females demonstrate a significant retruded maxilla and mandible as well as protruded lower incisor. However, no significant differnces were observe in mandibular inclination to the anterior cranial base, ANB angle, upper icisor protrusion and interincisal angle. Furthermore, when comparing the cephalometric norms of Omani Arabs[25] descent females with the present study result, it demonstrated that the Qatari and Omani Arab descent show no statistically significant differences in sagittal and vetical skeletal retationship. The sof tissue relationship indicates significant differences at 5\% level in upper lip to esthetic line and extremly significant in 
lower lip to Ricketts esthetic line. Also, the nasolabial angle in Omani Arab descent was significanty more obtused (105.3 degree) than in Qatari females (99.3). ( $\mathrm{P}<0.0001)$. The cephalometric norms in Saudi [26] were similar and revealed that there were no statiscally significant differences in most of the variables $(\mathrm{P}>0.05)$ except for the upper incisor proclination and mandibular inclination to the cranial base where Qatari females revealed higher mean values.( $\mathrm{P}<$ 0.05).It seems that most of the cephalometric norms of Omani and Saudi are very closed to the Qatari females than that in Jordainian and Emirati females.

Comparison with the Filipino females [27] (which belong to Oriental race) exhibited that; there were no statistical significant differences in the sagittal relatioship SNA \& SNB as well as in the maxillary inclination to the anterior cranial base NL-SNL $(\mathrm{P}>0.05)$. In the other hand, the interincisal angle was significantly reduced in Filipino females (113.6 degrees) when compared to Qatari females (122.28) which indicates bimaxillary protrusion of the incisors. The Filipino females also show significant posterior mandibular roation (ML-SNL) $\mathrm{P}<0.05$ ) whereas Qatari female exhibits very significant increased jaw angle (130.69) and highly significant skeletal Class II (ANB $=4$ degrees) angle. In contrast, the comparison of the cephalometric norms in Black Brazilian [28] demonstrated higher statisticaly significant differences in the sagittal relationship indicating prognathic maxilla and mandible than that in Qatari females. The dental relatioship displayed significant bixmaillary proclination and protrusion of lower incisors compared to Qatari females. The soft tissue relatioship of the Black Brazilian exhibited protruded lower lip due to increased proclination of lower incisor while no protrusion was observed in the upper lip. Moreover, the Nasobial angle was highly significantly acute in Black Brazilian whereas in Qatari females was slightly obtused $(\mathrm{P}>0.001)$.

When retrieving the previous studies conducted in Arab population, the bimaxillary proclination and protrusion of the upper and lower incisors were exisited in all even in Black and Oriental races.The same was also observed in Qatari females.[17], [24] - [26] This finding disagrees with results reported in Caucasians.[ 3,4] Such slightly more proclined incisors should be considered acceptable among Arabs, and patients should not be treated according to numbers. However, normal angulation of incisors should be taken into consideration, when incisor retraction is planned in orthodontic treatment.[24] However, several authors have pointed out that these populations are ethnically diverse and have questioned the rationale of attempting to define an Arab cephalometric norm.[29] - [31] It has been suggested that factors such as sex, age, and racial origin, as well as face type, contribute to this variation.[19] However, confirming the above results; Al-shammery et al stated "Within the limitations of this study, it was concluded that given the high level of heterogeneity it may not be feasible to speak of the different Arabic speaking nations as a distinct population for the purpose of developing norms for cephalometric skeletal relationships."[32] Therefore, the result of the present study confirms the conclusion of several investigations that each race would best be managed according to its individual characteristics. This in in order to achieve good functioning occlusion and an esthetically pleasing and harmonious face.
Finally, Cephalometric standards for Qatari females have been presented since, most subjects seeking orthodontic treatment are in this age range. The suggested norms should be of great value in the diagnosis of dentofacial discrepancy. Large sample is recommended for both sexes in order to establish cephalometric norms which will be of great help not only to the orthodontist but also useful to oral and maxillofacial surgeon when performing VTO or STO for an orthognathic surgery procedure to correct dental and skeletal abnormalities.

\section{CONFLICT OF INTEREST}

The authors declare no conflicts of interest.

\section{FUNDING}

No funding was received for this study

\section{ACKNOWLEDGMENT}

We would like to thank Hamad Medical Corporation/ Hamad Medical Research Center for sponsoring this research (Sub-Research Proposal Number 15041/150). The authors heartily acknowledge Professor Anil Sukumaran in preparing the final proof of the manuscript, Dr. Hashim AL-Hussain for his help in performing the statistical analysis and to Dr Mutaz Ahmed for editing the manuscript.

\section{REFERENCES}

[1] Broadbent, B. A new x-ray technique and its application to orthodontia." Angle Orthod.. 51(2): 93-114. 1931

[2] Hofrath $\mathrm{H}$. Bedeutung der röntgenfern und abstands aufnahme für die diagnostik der kieferanomalien. Fortschritte der Orthodontie 1 :231. 1931

[3] Downs, W. B. Variations In Facial Relationship: Their Significance In Treatment and Prognosis1. Angle Orthod.19(3): 145-55. 1949.

[4] Steiner, C. C. Cephalometrics for you and me." Am J Orthod. 39(10): 729-55. 1953.

[5] Tweed, C. H.. The Frankfort-Mandibular Incisor Angle (FMIA) In Orthodontic Diagnosis, Treatment Planning and Prognosis." Angle Orthod. 24(3): 121-69. 1954.

[6] Mills, J. R. E. Principles and Practice of Orthodontics.Churchill Livingstone, Edinburgh. 1982

[7] Sassouni, V. "A roentgenographic cephalometric analysis of cephalofacio-dental relationships. Am J Orthod. 41(10): 735-64.1955.

[8] Ricketts, R. M. Cephalometric Analysis And Synthesis." Angle Orthod. 67(2): 125-38. 1961.

[9] Jacobson, A. The Wits appraisal of jaw disharmony. Am J Orthod. 67(2): 125-38. 1975.

[10] McNamara, J. A., Jr. A method of cephalometric evaluation." Am J Orthod. 86(6): 449-69. 1984.

[11] Kavitha L and Karthik K. Comparison of cephalometric norms of caucasians and non-caucasians: A forensic aid in ethnic determination. J Forensic Dent Sci. Jan-Jun; 4(1): 53-55. 2012.

[12] Hideki Ioi, Shunsuke Nakata, Akihiko Nakasima, Amy L CountsComparison of cephalometric norms between Japanese and Caucasian adults in antero-posterior and vertical dimension. Eur J Orthodont;29:493-99. 2007.

[13] John Wu, Urban Hägg, Bakr A, Rabie M. Chinese norms of McNamara's cephalometric analysis. Angle Orthodont;77(1):12-20. 2007.

[14] Jagan Nath Sharma .Steiner's cephalometric norms for the Nepalese population. J Orthodont. 38:21-31. 2011.

[15] Guilherme Janson, Camila Leite Quaglio, Arnaldo pinzan, Eduardo Jacomino Franco, Marcos Roberto de Freitas. Craniofacial characteristics of Caucasian and Afro-Caucasian Brazilian subjects with normal occlusion. J Appl Oral Sci ;19(2):118-24. 2011.

[16] Emmanuel Olubusayo Ajayi. Cephalometric Norms of Nigerian Children. Am J Orthod Dentofac.Orthop. Nov;128(5):653-65. 2005.

[17] Hamdan A. M. Rock W. P. Cephalometric Norms in an Arabic Population. British Orthodontic Society..Vol 28 No. 297-300. 2001. 
[18] Kenza Lahlou, Asmae Bahoum, Myriam Boukili Makhoukhi, El Houssaine Aalloula. Comparison of dentolveolar protrusion values in Moroccans and other populations. Eur J Orthodont;32:430-34. 2010.

[19] Bishara, S. E., E. M. Abdalla and B. J. Hoppens. Cephalometric comparisons of dentofacial parameters between Egyptian and North American adolescents. Am J Orthod Dentofacial Orthop. 97(5): 41321. 1990.

[20] Hashim, H. A. and S. F. AlBarakati. Cephalometric soft tissue profile analysis between two different ethnic groups: a comparative study. J Contemp Dent Pract. 4(2): 60-73. 2003.

[21] Hassan, A. H. Cephalometric characteristics of Class II division 1 malocclusion in a Saudi population living in the western region. Saudi Dent J. 23(1): 23-27. 2011.

[22] Al Zain, T. and D. J. Ferguson "Cephalometric characterization of an adult Emirati sample with Class I malocclusion." J Orthod Sci._1(1): 11-15. 2012.

[23] AlBarakati SF, Kula KS, and Ghoneima AA.The reliability and reproducibility of cephalometric measurements: a comparison of conventional and digital methods. Dentomaxillofacial Radiology 41, 11-17. 2012.

[24] Huda M. Abu-Tayyem, Amna H. Alshamsi, Sayed Hafez, Eman Mohie EL-Din. Cephalometric norms for a sample of Emirates adults. Open Journal of Stomatology. 1, 75-83, 2011.

[25] Prashantha S. Govinakovi, Ibrahim Al-Busaidi, Viswapurna Senguttuvan. Cephalometric Norms in an Omani Adult Population of Arab Descent. Clinical \& basic research. May Vol. 18, Iss. 2, pp. 182189. 2018.

[26] Nasser M. AL-Jasser. Cephalometric Evaluation for Saudi Population Using the Downs and Steiner Analysis. J Contemp Dent Pract May;(6) 2:52-63.2005.

[27] Marlon Alvaro Moldez. Koshi Sato Junji Sugawara Hideo Mitani. Linear and Angular Filipino Cephalometric Norms According to Age and Sex. Angle Orthod 76 (5): 800-05. 2006.

[28] Lívia Maria Andrade de Freitas, Karina Maria Salvatore de Freitas, Arnaldo Pinzan,Guilherme Janson, Marcos Roberto de Freitas. A comparison of skeletal, dentoalveolar and soft tissue characteristics in white and black Brazilian subjects. J Appl Oral Sci.;18(2):135-42. 2010.

[29] Taibah SM, Feteih RM. Cephalometric features of anterior open bite. World. J Orthod. 8:145-52. 2007.

[30] Ousehal L, Jouhadi E, Bennani A. Vertical dimension of occlusion (VDO):Cephalometric norms for a Moroccan population. J Orofac Orthop. 77:39-44. 2016.

[31] Lateral Cephalometric Norms for Adolescent Kuwaitis: Hard Tissue Measurements Badreia Al-Jame, Jon Artun, Rashed Al-Azemi, Faraj Behbehani, Sana Buhamra. Med Princ Pract.15(2):91-97. 2006.

[32] Deema Ali Alshammery, Sarah Almubarak, Alhanouf Bin Hezaim, Razan Alkhunein, Sharat Chandra Pani, Hezekiah Mossadomi. Cephalometric norms of skeletal relationship among populations in selected Arab countries. A systematic review and meta-analysis. S J Oral Sci. Vol 3 No 269-74. 2016 